INTERNATIONAL JOURNAL OF MULTIDISCIPLINARY RESEARCH AND ANALYSis

ISSN(print): 2643-9840, ISSN(online): 2643-9875

Volume 04 Issue 02 February 2021

DOI: 10.47191/ijmra/v4-i2-06, Impact Factor: 6.072

Page No.- 142-144

\title{
The Effect of Independence, Learning Quality, And Learning Motivation on Swimming Learning Outcomes
}

\author{
Indria Apriyanty ${ }^{1}$, Fahmy Fachrezzy ${ }^{2}$, Oman Unju Subandi ${ }^{3}$, Ramdan Pelana ${ }^{4}$ \\ 1,2,3,4 Physical Education, Universitas Negeri Jakarta, Indonesia
}

\begin{abstract}
The purpose of this study was to determine the effect of independence, learning quality and learning motivation on swimming learning outcomes. The research sample was 30 participants in the Telaga Bestari Swimming Pool Course at Cikupa, Tangerang. The research approach used in this study is a multivariate associative approach, with survey methods and non-test techniques by distributing questionnaires. The technique used is the path analysis technique at a significance level of 0.05 . In general, the results of research based on the results of path analysis testing for each hypothesis obtained P-value $<0.05$ significance level, which means that each research hypothesis $(\mathrm{H} 1)$ is accepted. Which means that the conclusion of each research finding shows (1) there is a direct influence between each independent variable (Independence (X1), Learning Quality (X2), and Learning Motivation (X3)), (2) and there is a positive direct effect of each variable. free \{Independence (X1), Learning Quality (X2), and Learning Motivation (X3) on Swimming Learning Outcomes (Y). Thus the results of learning swimming can be influenced through increased independence, learning quality and learning motivation.
\end{abstract}

KEYWORDS: Independence, Learning Quality, Learning Motivation and Swimming Learning Outcomes.

\section{INTRODUCTION}

Swimming is a sport that is popular with all ages. Swimming itself is an activity of self-empowerment through a systematic, repetitive, and daily activity that adds to the workload.

Everyone has different goals in carrying out a sports activity. Swimming is not only about competition, there are many things that can be done according to the purpose to be done.

Coupled with the many swimming course places that are officially managed and private swimming services offered by sports students in collaboration with the swimming pool with all adequate facilities. One of them is swimming course services where the author works as a swimming coach at Telaga Bestari Swimming Pool Cikupa, Tangerang.

The swimming pool is an outdoor swimming pool located within the Sports Club Telaga Bestari Cikupa, Tangerang. Participants in swimming courses do not come from certain circles, this is evidenced by the large number of swimming course participants who come from various walks of life in the surrounding community, both near and far between early ages, children, adolescents, adults and the elderly.

While working as a swimming trainer, of course the author wants to know what factors affect the learning outcomes of swimming course participants at Telaga Bestari Cikupa, Tangerang. Among several factors, the writer decided to choose the participant's learning independence, the quality of learning received by the participants and motivation as the main factors that influenced the swimming learning outcomes of the swimming course participants at Telaga Bestari Cikupa, Tangerang.

\section{METHOD}

The research method used is an associative quantitative approach, with non-test techniques, while the analysis technique uses a path analysis approach, which is a technique for analyzing the causal relationship that occurs if the independent variable affects the dependent variable not only directly but also indirectly. So, "model path analysis is used to analyze the pattern of relationships between variables in order to determine the direct or indirect effect of a set of independent (exogenous) variables on the dependent variable (endogenous) (Riduwan, Engkos Achmad Kuncoro, 2012, 34)." The variables studied consisted of four variables consisting of three exogenous variables and one endogenous variable. The exogenous variables consist of Independence (X1), Learning Quality (X2). Learning Motivation (X3) and the endogenous variable are the Swimming Learning 


\section{The Effect of Independence, Learning Quality, And Learning Motivation on Swimming Learning Outcomes}

Outcomes (Y). The sample in this study is purposive sampling, which is a sample that is more than 10 years old and has been able to read and write as many as 30 people who are still active as participants in swimming courses at Al-Azhar Swimming Pool Kelapa Gading and are considered to have understood the questions that the researcher will ask.

\section{RESULT AND DISCUSSION}

First, there is a significant effect of Independence and Learning Quality together on Learning Motivation after testing the hypothesis which is proven jointly and individually and it has a significant effect on Learning Motivation. Structural equations from the results of path analysis from Independence and Learning Quality to Learning Motivation $X_{3}=1,82 X_{1}+3,015 X_{2}+0,0431$

$\varepsilon_{1}$

The magnitude of the contribution of the Independence and Learning Quality variables together on Learning Motivation is 98.6\% while the remaining $1.4 \%$ is the influence of other variables apart from the Independence and Learning Quality variables.

The contribution of the Independence variable to the Learning Motivation directly amounted to 0.664 or $66.4 \%$. Meanwhile, the Learning Quality variable has a direct contribution to Learning Motivation by 0.324 or $32.4 \%$.

These findings indicate, that to increase Learning Motivation, Course Participants must have a good perception of Independence and good learning quality, both of which have a $98.6 \%$ contribution to increasing Learning Motivation.

Second, there is a significant effect of Independence, Learning Quality and Learning Motivation together on Swimming Learning Outcomes. The structural equation from the results of the path analysis from Independence, Learning Quality and Learning Motivation together on Swimming Learning Outcomes is Sub-structure II: $Y=0,193 X_{1}+0,433 X_{2}+0,056 X_{3}+0.025 \varepsilon_{2}$.

The amount of the contribution of the Independence, Learning Quality and Learning Motivation variables together to the Swimming Learning Outcomes is $64.6 \%$ while the remaining $35.4 \%$ is the influence of other variables apart from the Independence, Learning Quality and Learning Motivation variables.

The direct contribution of the Independence variable to the Swimming Learning Outcomes is 0.408 or $40.8 \%$. The direct contribution of the Learning Quality variable to the Swimming Learning Outcomes is 0.270 or $27 \%$. Meanwhile, the direct contribution of the Learning Motivation variable to the Swimming Learning Outcomes was 0.322 or $32.2 \%$.

These findings indicate, that in order to improve the Swimming Learning Outcomes, Course Participants must have a good perception of Independence and Learning Quality as well as Learning Motivation.

The indirect effect of independence on learning outcomes swimming through learning motivation is 0.104 or $10.4 \%$. The indirect effect of learning quality on swimming learning outcomes through learning motivation is 0.211 or $21.1 \%$.

The total effect of Independence on Swimming Learning Outcomes through Learning Motivation is 0.986 or $98.6 \%$. The total effect of learning quality on swimming learning outcomes through learning motivation is 0.646 or $64.6 \%$.

These findings indicate that in order to improve the Swimming Learning Outcomes, it is necessary to pay attention to and improve the perception of Independence, Learning Quality and Learning Motivation because both directly and indirectly can improve the Swimming Learning Outcomes.

\section{CONCLUSIONS}

There is an influence of Independence (X1) on Swimming Learning Outcomes (Y). This means that the better the independence of a person, the better the swimming learning results will be obtained. Conversely, the lower the Independence, the lower the Swimming Learning Results obtained.

There is an effect of Learning Quality (X2) on Swimming Learning Outcomes (Y). This means that the better the quality of learning, the better the swimming learning results will be obtained. Conversely, the lower the Quality of Learning, the lower the Swimming Learning Results obtained.

There is an influence of Learning Motivation (X3) on Swimming Learning Outcomes ( $\mathrm{Y}$ ). This means that the better the Learning Motivation, the better the Swimming Learning Outcomes that will be obtained. Conversely, the lower the Learning Motivation, the lower the Swimming Learning Results obtained.

There is an influence of Independence (X1) on Learning Motivation (X3). This means that the better the independence, the better the learning motivation that will be obtained. Conversely, the lower the independence, the lower the motivation to learn. There is an influence of Learning Quality (X2) on Learning Motivation (X3) with Swimming Learning Outcomes (Y). This means that the better the quality of learning, the better the learning motivation that will be obtained. Conversely, the lower the Quality of Learning, the lower the Learning Motivation obtained.

There is an indirect effect of Independence (X1) on Swimming Learning Outcomes (Y) through Learning Motivation (X3). This means that the better the Independence will foster good Learning Motivation so as to result in good Swimming Learning 


\section{The Effect of Independence, Learning Quality, And Learning Motivation on Swimming Learning Outcomes}

Outcomes as well. Conversely, the lower the Independence, the lower the Learning Motivation, resulting in low Swimming Learning Outcomes.

There is an indirect effect of Learning Quality (X2) on Swimming Learning Outcomes (Y) through Learning Motivation (X3). This means that the better the quality of learning will foster good learning motivation, resulting in good swimming learning outcomes. Conversely, the lower the Quality of Learning, the lower the Learning Motivation, resulting in low Swimming Learning Outcomes.

\section{REFERENCES}

1) Achievements, J. O. (2018). Achievement Sports Journal, Volume 14, Number 1, January 2018 | 90. 14, 90-107.

2) Arifin, B. (2019). Development of Basic Swimming Movement for Elementary School Children. Journal of Primary School Thought and Development (JP2SD), 1 (1), 1. https://doi.org/10.22219/ip2sd.v1i1.1523

3) Aritonang, K. T. (2008). Interest and Motivation in Improving Student Learning Outcomes. Journal of Sower Education.

4) Djaali. (2008). Doc 14. In Djaali Educational Psychology.

5) E Ermawan Susanto. (2007). Dictate on swimming methodic learning. 1-16.

6) Firdausi, D. K. A. (2018). Improved Freestyle Swimming Learning Outcomes. JUARA: Sports Journal. https://doi.org/10.33222/juara.v3i1.216

7) Frandsen, A. N. (1961). Educational psychology in the modern school. Educational Psychology: The Principles of Learning in Teaching.

8) Gunarsa, S. D. (2011). Counseling and Psychotherapy. In Psychology.

9) Hamalik, O. (2003). Curriculum and Learning. jakarta: Bina Literacy.

10) Hamalik, O. (2011). Doc 17. In Teaching and Learning Process.

11) Masbur, M. (2015). Internalization of Educational Values from Abraham Maslow's Perspective (1908-1970) (Philosophical Analysis). EDUCATION JOURNAL: Counseling Guidance Journal. https://doi.org/10.22373/je.v1i1.316

12) Nasution, M. K. (2017). The use of learning methods in improving student learning outcomes. STUDIA DIDAKTIKA: Scientific Journal of Education.

13) Ngalim Purwanto. (2009). Teaching Evaluation Principles and Techniques. In PT Remaja Rosdakarya.

14) OLIH SOLIHIN, A., \& SRININGSIH. (2016). SMART LEARNING POOL

15) Pahlawan, U., \& Tambusaii, T. (2019). EDUCATIVE: SCIENCE EDUCATION JOURNAL. In Journal of Educational Sciences.

16) Ricardo, R., \& Meilani, R. I. (2017). The Impact of Learning Interest and Motivation on Student Learning Outcomes. Journal of Office Management Education. https://doi.org/10.17509/ipm.v2i2.8108

17) Sardiman. (2007). Doc 16. In Interaction and Teaching and Learning Motivation.

18) Slameto. (2003). Learning achievement. Journal of Education.

19) Sudjana, N. (2019). The Basics of the Teaching Process. In Bandung: Sinar Baru Algensindo.

20) Sugihartono, et al. (2007). Factors Affecting Learning Outcomes. Journal of Education.

21) Sukmawati, D., \& Hartoto, S. (2015). Application of Freestyle Swimming Learning to Free Style Swimming Learning Outcomes. Journal of Sports and Health Education, 03 (2), 366-370. Retrieved from http://ejournal.unesa.ac.id/index.php/jurnal-pend Pendidikan-jasmani/issue/archive

22) Surjobroto. (1984). educational psychology. jakarta: rajawali.

23) Uno, B. H. (2014). Motivation Theory \& Its Measurement. Personnel Review 